\title{
Correction to: MicroRNA-125b reverses oxaliplatin resistance in hepatocellular carcinoma by negatively regulating EVA1A mediated autophagy
}

Wei-Wei Ren ${ }^{1}$, Dan-Dan Li ${ }^{1}$ Xiaolan Chen², Xiao-Long Li ${ }^{1}$, Ya-Ping He ${ }^{1}$, Le-Hang Guo ${ }^{1}$, Lin-Na Liu' ${ }^{1}$ Li-Ping Sun ${ }^{1}$ and Xiao-Ping Zhang ${ }^{3}$

Correction to: Cell Death and Disease (2018) 9:547; https://doi.org/10.1038/s41419-018-0592-z; published online 10th August 2017.

Following publication of the article, the authors reported that Huixiong $\mathrm{Xu}$ had left the department, and requested that the author list be amended accordingly.
The PDF and HTML versions of the paper have been modified accordingly.

Published online: 24 August 2018

Correspondence: Li-Ping Sun (sunliping_s@126.com) or Xiao-Ping Zhang (zxpsibs@163.com)

'Department of Medical Ultrasound, Shanghai Tenth People's Hospital,

Ultrasound Research and Educational Institute, Tongji University School of Medicine, 200072 Shanghai, China

2Department of Radiotherapy, Shanghai Tenth People's Hospital, Ultrasound Research and Educational Institute, Tongji University School of Medicine, 200072 Shanghai, China

${ }^{3}$ Department of Interventional \& Vascular Surgery, Tongji University School of Medicine, 200072 Shanghai, China

(c) (i) Open Access This article is licensed under a Creative Commons Attribution 4.0 International License, which permits use, sharing, adaptation, distribution and reproduction BY in any medium or format, as long as you give appropriate credit to the original author(s) and the source, provide a link to the Creative Commons license, and indicate if changes were made. The images or other third party material in this article are included in the article's Creative Commons license, unless indicated otherwise in a credit line to the material. If material is not included in the article's Creative Commons license and your intended use is not permitted by statutory regulation or exceeds the permitted use, you will need to obtain permission directly from the copyright holder. To view a copy of this license, visit http://creativecommons.org/licenses/by/4.0/. 